\title{
MODEL MOTIVASI KERJA GURU BERDASARKAN SIGNIFIKASI TUGAS DAN PENGALAMAN PSIKOLOGI
}

\section{(A TEACHER WORK MOTIVATION MODEL BASED ON TASK SIGNIFICANCE AND PSYCHOLOGICAL EXPERIENCES)}

\author{
${ }^{1}$ Mat Zaini Abdullah, ${ }^{2}$ Rafisah Osman \& ${ }^{3}$ Fauziah Md. Jaafar \\ 1,2\&3Pusat Pengajian Pendidikan dan Bahasa Moden \\ Universiti Utara Malaysia, Malaysia

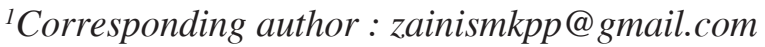

\begin{abstract}
ABSTRAK
Tujuan - Berdasarkan Job Characteristics Theory (JCT), kajian ini mengkaji kesan langsung signifikasi tugas terhadap motivasi kerja guru dan kesan tak langsung signifikasi tugas terhadap motivasi kerja guru melalui pengalaman psikologi. Secara khusus, kajian ini menilai peranan signifikasi tugas dan pengalaman psikologi berasaskan rangka kerja pengajaran untuk menerangkan motivasi kerja guru.
\end{abstract}

Metodologi - Kajian ini menggunakan reka bentuk tinjauan. Seramai 497 sampel guru dipilih dengan menggunakan teknik pensampelan rawak berkelompok daripada populasi guru sekolah menengah kebangsaan harian biasa di negeri Kedah berjumlah 12,005 orang. Data kajian diperoleh melalui soal selidik yang mengandungi 22 item. Data dianalisis menggunakan pemodelan persamaan struktur dan analisis regresi PROCESS MACRO.

Dapatan - Dapatan kajian menunjukkan signifikasi tugas dan pengalamanpsikologi(pengalamankerjayangbermakna, pengalaman kebertanggungjawaban terhadap hasil kerja dan pengetahuan sebenar hasil kerja) secara signifikan mempengaruhi motivasi kerja guru. Penilaian keseluruhan model menunjukkan tahap kesepadanan model adalah munasabah. Dapatan analisis regresi PROCESS 
$M A C R O$ menunjukkan pengalaman psikologi (pengalaman kerja yang bermakna, pengalaman kebertanggungjawaban terhadap hasil kerja dan pengetahuan sebenar hasil kerja) merupakan pengantara separa dalam hubungan signifikasi tugas dengan motivasi kerja guru. Berbanding pengalaman kerja yang bermakna dan pengalaman kebertanggungjawaban terhadap hasil kerja, kesan signifikasi tugas melalui pengetahuan sebenar hasil kerja terhadap motivasi kerja guru adalah lebih kuat.

Signifikan - Kajian menghasilkan model yang menunjukkan kepentingan signifikasi tugas dan pengalaman psikologi (pengalaman kerja yang bermakna, pengalaman kebertanggungjawaban terhadap hasil kerja dan pengetahuan sebenar hasil kerja) sebagai penyumbang yang signifikan kepada motivasi kerja guru.

Kata Kunci - Job Characteristics Theory, pemodelan persamaan struktur, signifikasi tugas, pengalaman psikologi, motivasi kerja guru.

\section{ABSTRACT}

Purpose - Based on Job Characteristics Theory (JCT), the study examined direct and indirect precursors of task significance and psychological experiences to explain teacher work motivation.

Methodology - This study employed a survey design. A sample of 497 teachers out of a 12005- strong population was selected from National Secondary Schools in the state of Kedah. Cluster random sampling was used to select the samples. Data were obtained through a survey questionnaire that comprised 22 items and these were analysed using structural equation modelling and regression analysis with PROCESS MACRO.

Findings - Results indicated that task significance and psychological experiences (experienced meaningfulness of the work, experienced responsibility for outcomes of the work and knowledge of actual results of the work) significantly influenced teacher work motivation. Based on the model evaluation, the overall measurement model and the structural model were found to be adequately fit. The findings of regression analysis with PROCESS MACRO indicated that 
psychological experiences (experienced meaningfulness of the work, experienced responsibility for outcomes of the work and knowledge of actual results of the work) partially mediated the relationship of task significance and teacher work motivation. Compared to experienced meaningfulness of the work and experienced responsibility for outcomes of the work, task significance seemed to exhibit a stronger impact on teacher work motivation through knowledge of actual results of the work.

Significance - The study proposed a model which highlighted the importance of task significance and psychological experiences (experienced meaningfulness of the work, experienced responsibility for outcomes of the work and knowledge of actual results of the work) as significant contributors to teacher work motivation.

Keywords - Job Characteristics Theory, structural equation modelling, task significance, psychological experiences, teacher work motivation.

\section{PENGENALAN}

Motivasi kerja dalam kalangan guru mempunyai implikasi yang signifikan kepada kepimpinan pendidikan dan pengurusan sekolah kerana kesannya terhadap motivasi pelajar untuk belajar (Jesus \& Lens, 2005; Hobson, Ashby, McIntyre \& Malderez, 2010; Subasi, 2009). Semasa mengajar, guru juga berperanan untuk memotivasikan pelajar untuk belajar. Namun terdapat dalam kalangan guru menganggap usaha memotivasikan pelajar untuk belajar adalah sukar, sedangkan bagi kepimpinan pendidikan isu yang paling penting ialah bagaimana guru boleh memotivasikan pelajar sekiranya diri guru kurang bermotivasi (Ashley \& Trisha, 2013; Hobson et. al, 2010; Subasi, 2009). Dalam hal ini, motivasi kerja guru dianggap penting kerana kehadirannya boleh mempengaruhi kualiti pengajaran, prestasi dan kecekapan guru (Kinicki \& Williams, 2003; M.Nur Mustafa \& Norasmah Othman, 2010; Hein, Ries, Pires, Emeljanovas, Ekler \& Valantnine, 2012).

Usaha meningkatkan motivasi kerja guru untuk melaksanakan pengajaran telah dilakukan oleh Kementerian Pendidikan Malaysia melalui kenaikan gaji sebanyak $15 \%$ hingga $25 \%$ pada tahun 
2007. Penambahbaikan Sistem Saraan Malaysia (SSM) telah menyebabkan gaji guru sekali lagi dinaikkan antara $7 \%$ hingga 13\% bermula Januari 2012 (Jabatan Perkhidmatan Awam, 2007; Saifulizam Mohamad, 2011). Kajian-kajian lepas menunjukkan penggunaan ganjaran ektrinsik seperti gaji dapat meningkatkan motivasi kerja (Akintoye, 2000; Muhamad Ali Embi \& Syamsir Saili, 2013; Muhamad Ali Embi, 2006) dan boleh meningkatkan kesan positif terhadap tingkah laku kerja (Gagne \& Forest, 2008; Lawler, 1983). Walau bagaimanapun kajian Akademi Kepimpinan Pengajian Tinggi (AKEPT) melibatkan 41 buah sekolah dengan 125 pengajaran mendapati $50 \%$ prestasi pengajaran guru berada pada tahap kurang memuaskan dan dapatan penaziran melaporkan hanya 13\% sekolah mencapai tahap prestasi pengajaran cemerlang (Kementerian Pelajaran Malaysia, 2012).

Job Characteristics Theory (JCT) mencadangkan kualiti interaksi antara pekerja dengan rangka kerja yang disediakan oleh organisasi boleh meningkatkan produktiviti organisasi apabila rangka kerja berperanan sebagai sumber motivasi kerja (Hackman \& Oldham, 1980). Walau bagaimanapun penggubalan rangka kerja pengajaran guru di Malaysia lebih memfokuskan kepada keberhasilan pelajar dari aspek meningkatkan penguasaan ilmu pengetahuan, maklumat, kemahiran dan perubahan tingkah laku, di samping pencapaian dasar-dasar pendidikan negara serta aspirasi Falsafah Pendidikan Kebangsaan (Abu Bakar Nordin \& Ikhsan Othman, 2003; Mohamad Khairi Othman \& Asmawati Suhid, 2010; Kementerian Pelajaran Malaysia, 2012). Sebaliknya, penggubalan rangka kerja pengajaran kurang dikaitkan dengan usaha untuk meningkatkan keberhasilan guru dari aspek motivasi kerja (Nazila \& Seyed, 2014). Oleh itu, kajian ini dilakukan untuk menilai sejauh mana signifikasi tugas dalam rangka kerja pengajaran boleh mempengaruhi motivasi kerja guru melalui pengantaraan tiga pengalaman psikologi.

Kajian-kajian lepas tentang hubungan antara signifikasi tugas dengan motivasi kerja lebih memberikan tumpuan kepada bidang pekerjaan seperti kejururawatan, perbankan, komunikasi dan teknologi, perakaunan, sumber manusia, logistik, jualan, kesihatan, peruncitan, profesional bidang maklumat dan perhotelan (Hala \& Neamat, 2012; Azash, Safare, Thirupalu \& Subhan, 2012; Mahfuz, 2012; Mahesh, 2010; Adebayo \& Ezeanya, 2010; Casey \& Robins, 
2008). Namun kurang kajian yang dibuat dalam bidang pendidikan dengan guru sebagai responden khususnya di Malaysia.

Dalam proses teori, JCT mencadangkan tiga pengalaman psikologi terdiri daripada pengalaman kerja yang bermakna, pengalaman kebertanggungjawaban terhadap hasil kerja dan pengetahuan sebenar hasil kerja sebagai pengantara dengan matlamat untuk memahami bagaimana proses motivasi kerja boleh berlaku melalui rangka kerja yang disediakan (Hackman \& Oldham, 1980). Walau bagaimanapun kajian-kajian rangka kerja menggunakan JCT sebagai kerangka teoritikal hanya menguji laluan c, iaitu kesan langsung signifikasi tugas terhadap motivasi kerja tanpa pengalaman psikologi sebagai pengantara (Misalnya kajian Isfahani, Bahrami \& Torki, 2013; Gomes, Asseiro \& Ribeiro, 2013; Nadeem, Anwar \& Shaikh, 2013; Azash et al, 2012; Aneel, Qaisar, Ikhtiar \& Ashi, 2011; Hala \& Neamat, 2012; Abu Zafar, Shah Johir, Fazlul \& Faijul, 2013; Casey, Desplas, Rossmaier \& Hilton, 2012; Rabia \& Adnan, 2010; Mahesh, 2010). Situasi ini telah menyebabkan penjelasan mekanisme hubungan antara signifikasi tugas dengan motivasi kerja melalui pengalaman psikologi kekal terhad.

Sementara itu, implikasi daripada kegagalan menguji pengalaman psikologi sebagai pengantara telah menyebabkan kajian-kajian lepas (Misalnya kajian Isfahani et. al, 2013; Gomes et. al, 2013; Nadeem et. al, 2013; Azash et al, 2012; Aneel et. al, 2011; Hala \& Neamat, 2012; Abu Zafar et. al, 2013) tidak meneliti kesan langsung (laluan c') signifikasi tugas terhadap motivasi kerja bersekali dengan pengalaman psikologi. Sebaliknya kesan keseluruhan telah dianggap sebagai kesan langsung signifikasi tugas terhadap motivasi kerja. Mengikut pendekatan kesan tak langsung, kesan keseluruhan adalah nilai operasi tambah antara kesan langsung (laluan c) dengan kesan tak langsung (laluan a dan laluan b). Kesan keseluruhan tidak mewakili kesan langsung (laluan c') pemboleh ubah bebas terhadap pemboleh ubah bersandar kerana tidak melibatkan pemboleh ubah pengantara (Hayes, 2009, 2013; Hayes \& Preachers, 2010). Dalam hal ini, dapatan kajian-kajian lepas telah menimbulkan persoalan dari aspek ketepatan analisis kesan langsung signifikasi tugas terhadap motivasi kerja. Sehubungan itu, kajian ini berusaha meneliti kesan langsung (laluan c') signifikasi tugas terhadap motivasi kerja bersekali dengan pengalaman psikologi sebagai pengantara hubungan dan diuji secara serentak. 
Selain itu, analisis meta (Behson, 2012; Humphrey, Nahrgang \& Morgeson, 2007) menunjukkan hubungan yang tidak konsisten antara signifikasi tugas dengan pengalaman psikologi. JCT mencadangkan hanya signifikasi tugas memberi kesan langsung yang signifikan terhadap pengalaman kerja yang bermakna (Hackman \& Oldham, 1980), namun analisis meta menunjukkan signifikasi tugas juga turut memberi kesan langsung yang signifikan terhadap pengalaman kebertanggungjawaban terhadap hasil kerja dan pengetahuan sebenar hasil kerja (Behson, 2012; Humphrey et. al, 2007). Sifat tidak konsisten pemboleh ubah signifikasi tugas dalam mempengaruhi pengalaman psikologi memerlukan satu kajian baru dilakukan melalui model peluasan pengaruh signifikasi tugas terhadap pengalaman psikologi dan dianalisis secara serentak dengan menggunakan data yang sama di samping menguji kemungkinan wujud kesan pengantaraan pelbagai pengalaman psikologi bagi hubungan antara signifikasi tugas dengan motivasi kerja.

Walaupun kajian yang meneliti kesan langsung antara pengalaman psikologi dengan motivasi kerja telah dilakukan dalam sektor perkhidmatan di luar negara, namun tidak melibatkan sektor perkhidmatan pendidikan dan dapatannya adalah berbeza mengikut jenis sampel yang dikaji (Toode, Routasalo, Helmian \& Souminen, 2014; Shani \& AnandKumar, 2011). Motivasi kerja dalam kalangan jururawat Hospital Estonian adalah lebih tinggi apabila rangka kerja dinilai amat bermakna kepada responden (Toode et. al, 2014) sebaliknya kakitangan perbankan di Coimbatore, Tamil Nadu, India lebih bermotivasi dalam melaksanakan kerja apabila rangka kerja yang dilaksanakan dinilai dapat membina rasa kebertanggungjawaban terhadap hasil kerja (Shani \& AnandKumar, 2011). Bagi mengisi jurang yang ditinggalkan, kajian ini berusaha meneliti kesan langsung pengalaman psikologi dengan motivasi kerja berasaskan sampel guru dalam sektor perkhidmatan pendidikan di Malaysia.

\section{OBJEKTIF KAJIAN}

Kajian ini secara umumnya bertujuan membangunkan model motivasi kerja guru berdasarkan signifikasi tugas dan pengalaman psikologi. Sementara objektif utama kajian ini adalah untuk meneliti 
kesan langsung signifikasi tugas terhadap pengalaman psikologi, kesan langsung pengalaman psikologi terhadap motivasi kerja guru dan kesan langsung dan tak langsung signifikasi tugas terhadap motivasi kerja guru.

\section{SOROTAN KARYA}

Job Characteristics Theory (JCT) mengandaikan signifikasi tugas hanya mempunyai hubungan dengan motivasi kerja melalui kesan pengantaraan pengalaman kerja yang bermakna (Hackman \& Oldham, 1980). Andaian ini disokong oleh beberapa kajian yang menunjukkan terdapat kesan pengantaraan yang signifikan pengalaman kerja yang bermakna terhadap hubungan antara signifikasi tugas dengan motivasi kerja (Shani \& AnandKumar, 2011; Humphrey et. al, 2007; Behson, Eddy \& Lorenzat, 2000; Renn \& Vandenberg, 1995). Sebaliknya JCT tidak mengandaikan pengalaman kebertanggungjawaban terhadap hasil kerja dan pengetahuan sebenar hasil kerja sebagai pengantara yang signifikan bagi hubungan signifikasi tugas dengan motivasi kerja (Hackman \& Oldham, 1980). Signifikasi tugas dalam kajian ini merujuk kepada sejauh mana rangka kerja pengajaran menyediakan peluang kepada guru untuk merasai impak atau kesan positif yang terhasil daripada pelaksanaan pengajaran terhadap kehidupan orang lain sama ada di sekolah atau di luar sekolah. Signifikasi tugas wujud sekiranya pelaksanaan pengajaran menyebabkan guru merasakan pengajaran yang dilakukan memberi kesan yang bermakna kepada kehidupan orang lain, penting kepada pembangunan negara, mempunyai kesan yang besar kepada pelajar dan memberi kesan yang bermakna kepada masyarakat.

JCT yang menjadi kerangka teoritikal utama kajian ini merupakan teori reka bentuk kerja yang menekankan pembinaan motivasi kerja berasaskan ciri-ciri kerja yang bersifat intrinsik seperti signifikasi tugas (Hackman \& Oldham, 1980; Champoux, 2011; Faturochman, 1997). Mengikut JCT, motivasi kerja yang dikaji diistilahkan sebagai motivasi kerja dalaman (internal work motivation) yang merujuk kepada perasaan positif yang dialami secara dalaman apabila pekerja dapat melaksanakan kerja dengan berkesan atau baik (Hackman \& Oldham, 1980). Motivasi kerja dalaman terbentuk 
berasaskan anteseden yang tidak kelihatan dalam kandungan kerja melalui pembinaan pengalaman psikologi dalam diri pekerja seterusnya merangsang perasaan positif sebagai salah satu elemen penting motivasi kerja (Hackman \& Oldham, 1980; Oldham, 1976). Dalam hal ini, proses merangsang dan meningkatkan motivasi kerja guru adalah penting bagi mencapai keberkesanan pengajaran pada tahap yang maksimum (Norashid Othman \& Hamzah Md. Omar, 2014).

Dalam kajian ini, pengalaman kerja yang bermakna merujuk kepada pengalaman pengajaran yang boleh memberi makna secara peribadi dan dianggap berharga kepada guru mengikut sistem nilai yang menjadi pegangan mereka. Bessette (2003) menekankan pengalaman kerja bermakna sebagai persepsi positif secara dalaman terhadap kerja yang menjadi keperluan asas untuk mencari makna dan tujuan utama dalam melakukan kerja. Pengalaman kerja juga dianggap sebagai perasaan positif yang terhasil daripada interaksi antara pekerja dengan organisasi kerja dan rangka kerja (Kristensen, Hannerz, Hogh \& Borg, 2005), manakala Treadgold (1999) menganggapnya sebagai persepsi positif terhadap kerja yang menjadi faktor individu dimotivasikan secara intrinsik untuk melaksanakan kerja dan rasa untuk melaksanakannya dipandu oleh dorongan dalaman. Dalam hal ini, Yalom (1980) menegaskan manusia memerlukan pengalaman yang bermakna untuk memahami dan mentafsirkan pengalaman mereka dalam melaksanakan kerja serta mendefinisikan nilai-nilai yang menjadi asas tindakan mereka.

Pengalaman bertanggungjawab terhadap hasil kerja merupakan perasaan kebertanggungjawaban dan rasa akauntabiliti guru secara peribadi terhadap hasil pengajaran yang dilakukan. Dalam konteks guru, pengalaman kebertanggungjawaban merupakan salah satu faktor penting yang mempengaruhi keberhasilan proses pengajaran dan pembelajaran (Dahlgren \& Hammar, 2009; Lauermann \& Karabenick, 2011, 2013). Pengalaman kebertanggungjawaban menjelaskan rasa dalaman dan komitmen untuk menyumbang kepada keberhasilan matlamat kerja dan mempertahankan keberhasilan matlamat tersebut (Lauermann \& Karabenick, 2011). Pengalaman kebertanggungjawaban boleh melibatkan perasaan guru terhadap amalan pengajaran, pembelajaran pelajar dan prestasi pelajar (Lauermann \& Karabenick, 2013), selain melibatkan 
rasa tanggungjawab terhadap motivasi pelajar untuk belajar, kejayaan akademik pelajar dan tanggungjawab dalam interaksi guru dengan pelajar (Lauermann \& Karabenick, 2013). Oleh itu, pengalaman kebertanggungjawaban memerlukan guru memahami secara mendalam tentang tanggungjawab mereka dan situasi yang memerlukan mereka bertanggungjawab secara peribadi untuk setiap hasil kerja yang dilakukan (Lauermann \& Karabenick, 2013).

Faktor terakhir pengalaman psikologi yang diuji dalam kajian ini ialah pengetahuan sebenar hasil kerja yang merupakan kefahaman dan pengetahuan yang jelas serta berterusan guru terhadap keberkesanan atau kecekapan mereka dalam melaksanakan pengajaran. Dalam soal ini, Dewey (1933) menegaskan individu yang mempunyai pengetahuan sebenar hasil kerja sentiasa aktif dalam memikirkan masalah yang dihadapi, gigih mencari jalan penyelesaian, sedia mengorbankan masa untuk memastikan masalah yang dihadapi dapat diatasi dan sentiasa menerima pandangan yang berpotensi untuk menyelesaikan masalah. Bagi Boud, Keogh dan Walker (1985) pengetahuan sebenar hasil kerja berperanan meneutralkan kembali segala perasaan negatif yang menyelubungi pengalaman yang lalu supaya satu perspektif baru dapat dihasilkan daripada pengalaman tersebut sekaligus mengubah tingkah laku dan tindakan seseorang.

\section{METODOLOGI}

Kajian ini menggunakan reka bentuk tinjauan yang melibatkan pengujian pemodelan persamaan struktur untuk menjelaskan hubungan signifikasi tugas dalam rangka kerja pengajaran dengan motivasi kerja guru melalui proses pengantaraan pengalaman psikologi dan fenomenanya pada masa sekarang (Gay \& Diehl, 1996). Kaedah tinjauan dianggap sesuai digunakan kerana sampel bertaburan dalam saiz populasi yang besar tetapi saiz sampel telah ditentukan oleh penyelidik dan maklumat dapat dikumpulkan pada satu titik masa tertentu (single point in time) (Noraini Idris, 2010; Creswell, 2012; Cohen, Manion \& Morrison, 2011). Penggunaan kaedah tinjauan juga merupakan cara terbaik bagi mengukur persepsi, sikap, kepercayaan, pendapat, praktis dan orientasi untuk 
saiz populasi yang besar (Babbie, 2008; Creswell, 2012). Mengikut Richey dan Klein (2007), kaedah tinjauan sering digunakan bagi kajian yang berkait dengan pembangunan atau pengujian teori, sekiranya ralat dapat dikawal, dapatan kajian boleh digeneralisasikan kepada populasi (Miller, 2003).

Sampel dalam kajian adalah seramai 497 orang dari populasi guru sekolah menengah kebangsaan harian biasa di negeri Kedah yang berjumlah 12, 005 orang (Jabatan Pendidikan Kedah, 2014). Kaedah pemilihan sampel menggunakan teknik pensampelan rawak berkelompok (Chua, 2011; Noraini Idris, 2010; Ahmad Mahdzan Ayob, 2007). Peringkat pertama individu guru sekolah menengah kebangsaan harian biasa sebagai unit analisis dikelompok berdasarkan sekolah mengikut daerah pendidikan masing-masing dan setiap sekolah dianggap sebagai satu kelompok untuk tujuan pensampelan. Peringkat kedua setiap sekolah diberi nombor siri daripada 1 hingga 113 mengikut daerah pendidikan supaya semua sekolah mempunyai peluang yang sama untuk dipilih mewakili daerah pendidikan masing-masing dan bertujuan mewujudkan keseimbangan dari segi bilangan sekolah untuk setiap daerah pendidikan. Peringkat ketiga daripada 113 kelompok sekolah sebanyak 20 buah sekolah (5 buah sekolah bagi setiap daerah pendidikan) telah dipilih dengan menggunakan teknik pensampelan rawak mudah. Setiap sekolah diwakilli oleh 30 orang guru sebagai sampel yang dipilih menggunakan teknik pensampelan rawak mudah. Kajian ini telah melibatkan empat daerah pentadbiran pendidikan di negeri Kedah.

\section{INSTRUMEN KAJIAN}

Kajian ini menggunakan instrumen Work Design Questionnaire (WDQ) oleh Morgeson dan Humphrey (2006) yang diadaptasi bagi mengukur signifikasi tugas. Seterusnya pemboleh ubah pengalaman psikologi dan motivasi kerja guru diukur dengan mengubahsuai instrumen asal Job Diagnostics Survey (JDS) oleh Hackman dan Oldham (1975). Faktor signifikasi tugas diukur dengan menggunakan 4 item, faktor pengalaman kerja yang bermakna (4 item), pengalaman kebertanggungjawaban terhadap hasil kerja (6 item), pengetahuan sebenar hasil kerja (4 item) dan motivasi kerja guru (4 item). Kesemua item berbentuk pernyataan positif kecuali 
6 item, iaitu dua item (PM6 dan PM8) yang mengukur pengalaman kerja yang bermakna, satu item (PB12) yang mengukur pengalaman kebertanggungjawaban terhadap hasil kerja, dua item (PS16 dan PS18) yang mengukur pengetahuan sebenar hasil kerja dan satu item (MK22) yang mengukur motivasi kerja guru. Kesemua item dikod semula secara terbalik pada item yang sama untuk tujuan analisis. Instrumen kajian ini menggunakan skala jenis LIKERT lima mata dengan 1 = sangat tidak bersetuju; $2=$ tidak bersetuju; $3=$ sederhana setuju; 4 = bersetuju dan $5=$ sangat bersetuju.

Bagi memperoleh kesahan muka, item-item asal telah diterjemahkan oleh Institut Terjemahan dan Buku Malaysia (ITBM). Kemudian disemak oleh dua orang guru bahasa Inggeris berasaskan kaedah back translation (Brislin, 1970). Bagi semakan struktur ayat bahasa Melayu, penyelidik telah menggunakan khidmat dua orang guru bahasa Melayu yang berpengalaman. Lima orang guru dipilih untuk diuji kefahaman mereka terhadap item-item melalui proses menjawab instrumen dan soal jawab lisan. Sebelum diedarkan untuk pungutan data sebenar, instrumen disemak sekali lagi oleh dua orang pensyarah di Universiti Utara Malaysia. Pungutan data dibuat dengan menggunakan kaedah serahan tangan setelah kebenaran daripada Kementerian Pendidikan Malaysia dan Jabatan Pendidikan Negeri Kedah serta pengetua sekolah berkaitan diperoleh.

\section{ANALISIS DATA}

Analisis faktor pengesahan menggunakan perisian AMOS 21 dilakukan untuk tujuan kesahan konstruk. Kesahan konstruk dinilai daripada tiga aspek, iaitu kesahan menumpu, kesahan membeza dan kesahan nomologikal (Hair, Black, Babin \& Anderson, 2010). Seterusnya, analisis pemodelan persamaan struktur dilaksanakan untuk meneliti kesan langsung signifikasi tugas terhadap pengalaman psikologi dan pengalaman psikologi terhadap motivasi kerja guru. Kaedah bootstrapping dengan pensampelan semula 5000 kali melibatkan selang keyakinan 95\% bias diperbetulkan (Bias Corrected 95\% Confident Interval) digunakan. Analisis regresi PROCESS MACRO IBM SPSS 21 juga melibatkan kaedah bootstrapping dengan pensampelan semula sebanyak 5000 kali dan 95\% selang keyakinan bias diperbetulkan (Bias corrected 95\% 
Confident Interval) digunakan untuk menilai kesan langsung dan tak langsung signifikasi tugas terhadap motivasi kerja guru. Analisis regresi ini melibatkan proses impute pemboleh-pemboleh ubah kajian dalam model pengukuran keseluruhan bagi membentuk skor faktor (Preachers \& Hayes, 2008). Nisbah kesan bagi perbandingan kesan pengantaraan yang lebih signifikan antara pemboleh ubah pengantara digunakan dalam kajian ini kerana dianggap lebih baik berbanding penggunaan kaedah pengantara penuh atau separa (Shrout \& Bolger, 2002). Rumus bagi mengira nisbah kesan sebagaimana di bawah:

$$
\text { Nisbah Kesan }=\frac{\text { Kesan tak langsung }}{\text { Kesan keseluruhan }}
$$

\section{Analisis Faktor Pengesahan}

Rajah 1 menunjukkan model pengukuran keseluruhan lima pemboleh ubah kajian yang telah mencapai tahap kesepadanan. Kriteria tahap kesepadanan dinilai berasaskan cadangan Hair et. al (2010), iaitu satu petunjuk Absolute Fit Index (AFI), satu petunjuk Incremental Fix Index (IFI) dan satu petunjuk Parsimony Fit Index (PFI) sebagai tambahan kepada nilai khi kuasa dua $\left(\chi^{2}\right)$.

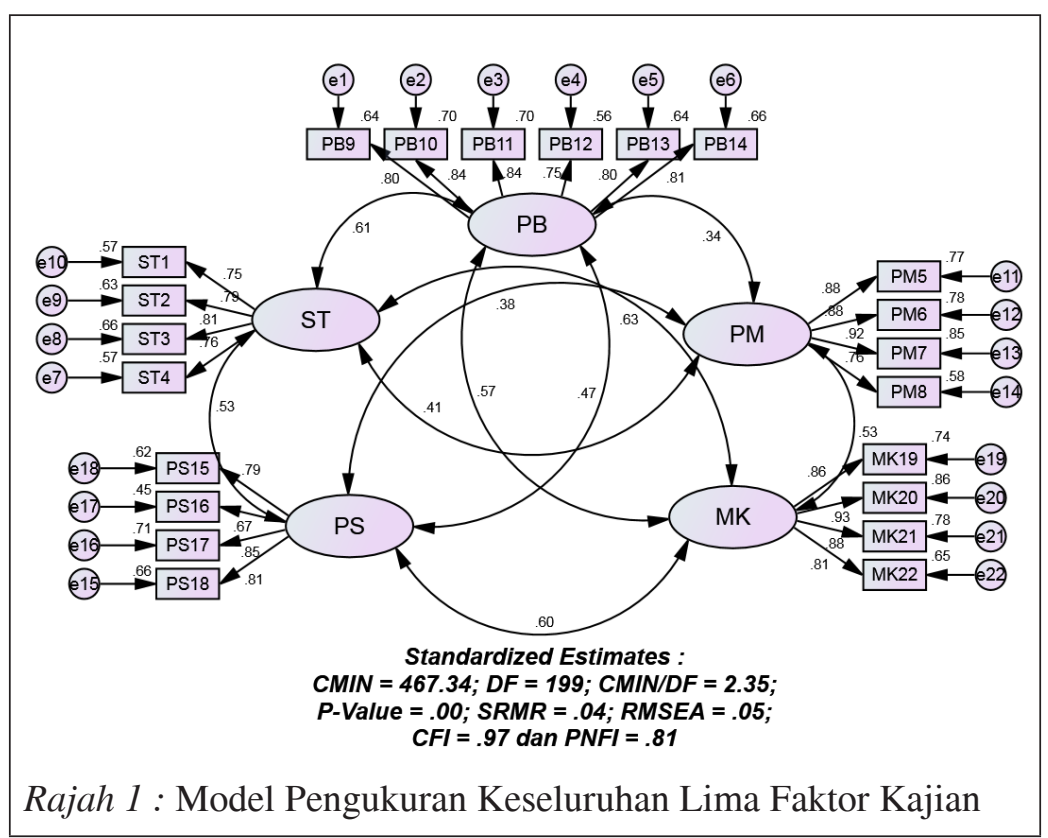


Nota $:$ ST = Signifikasi tugas; $\mathrm{PM}=$ Pengalaman kerja yang bermakna; $\mathrm{PB}=$ Pengalaman kebertanggungjawaban terhadap hasil kerja; PS = Pengetahuan sebenar hasil kerja; MK = Motivasi kerja

Sementara itu, jadual 1 menunjukkan tiga petunjuk AFI memberi nilai tahap padanan yang baik, iaitu $\mathrm{CMIN} / \mathrm{DF}=2.35$, SRMR $=$ .04 dan RMSEA $=.05$. Ketiga-tiga petunjuk memenuhi nilai yang ditetapkan (Hair et. al, 2010). Bagi petunjuk IFI, nilai CFI $=.97$ melebihi nilai .90 yang ditetapkan berdasarkan kerumitan model dan saiz sampel. Walaupun model ini tidak dibandingkan dengan model lain, Parsimony Fit Index (PFI) turut diambil kira. Nilai PNFI $=.81$ melebihi .60 menunjukkan model pengukuran keseluruhan lima pemboleh ubah kajian mencapai tahap kesepadanan yang baik dengan data kajian dan sesuai digunakan untuk analisis selanjutnya.

\section{Jadual 1}

Tahap Kesepadanan Model Pengukuran Keseluruhan Lima Faktor Kajian

\begin{tabular}{lcc}
\hline \multicolumn{1}{c}{ Petunjuk } & $\begin{array}{c}\text { Nilai Petunjuk } \\
\text { Diterima }\end{array}$ & $\begin{array}{c}\text { Model Pengukuran } \\
\text { Keseluruhan }\end{array}$ \\
\hline Absolute Fit Indices & & \\
CMIN $\left(\chi^{2}\right)$ & - & 467.34 \\
DF & - & 199 \\
CMIN/DF & $<.03$ & 2.35 \\
PROB (P-Val) & $>.05$ & .00 \\
SRMR & $<.08$ & .04 \\
RMSEA & $<.08$ & .05 \\
Incremental Fit Indices & & .97 \\
CFI & $>.90$ & \\
Parsimony Fit Indices & & .81 \\
PNFI & $>.60$ & \\
\hline
\end{tabular}

\section{Kesahan Menumpu}

Jadual 2 menunjukkan wujud kesahan menumpu item-item untuk mengukur setiap pemboleh ubahnya apabila nilai kebolehpercayaan konstruk (Pc) melebihi .60 dan lebih besar berbanding purata varians teresktrak (AVE) dengan nilai AVE melebihi .50 (Hair et. al, 2010). 
Jadual 2

Kesahan Menumpu Lima Pemboleh Ubah Kajian

\begin{tabular}{|c|c|c|c|c|c|c|}
\hline Bil & Faktor & Item & $\lambda$ & SMC & Pc & AVE \\
\hline \multirow[t]{4}{*}{1} & ST & ST1 & .75 & .57 & .86 & .61 \\
\hline & & ST2 & .79 & .63 & & \\
\hline & & ST3 & .81 & .66 & & \\
\hline & & ST4 & .76 & .57 & & \\
\hline \multirow[t]{4}{*}{2} & PM & PM5 & .88 & .77 & .92 & .75 \\
\hline & & PM6 & .88 & .78 & & \\
\hline & & PM7 & .92 & .85 & & \\
\hline & & PM8 & .76 & .58 & & \\
\hline \multirow[t]{6}{*}{3} & PB & PB9 & .80 & .64 & .92 & .65 \\
\hline & & PB10 & .84 & .70 & & \\
\hline & & PB11 & .84 & .70 & & \\
\hline & & PB12 & .75 & .56 & & \\
\hline & & PB13 & .80 & .64 & & \\
\hline & & PB14 & .81 & .66 & & \\
\hline \multirow[t]{4}{*}{4} & PS & PS15 & .79 & .62 & .86 & .61 \\
\hline & & PS16 & .67 & .45 & & \\
\hline & & PS17 & .85 & .71 & & \\
\hline & & PS18 & .81 & .66 & & \\
\hline \multirow[t]{4}{*}{5} & MK & MK19 & .86 & .74 & .93 & .76 \\
\hline & & MK20 & .93 & .86 & & \\
\hline & & MK21 & .88 & .78 & & \\
\hline & & MK22 & .81 & .65 & & \\
\hline
\end{tabular}

Nota $:$ ST = Signifikasi tugas; $\mathrm{PM}=$ Pengalaman kerja yang bermakna; $\mathrm{PB}=$ Pengalaman kebertanggungjawaban terhadap hasil kerja; PS = Pengetahuan sebenar hasil kerja; MK = Motivasi kerja; $\lambda=$ Beban faktor; SMC $=$ Squared multiple correlation (korelasi kuasa dua berganda); $\mathrm{Pc}=$ Construct reliability (kebolehpercayaan konstruk); AVE = Average variance extracted (purata varians terestrak).

\section{Kesahan Membeza}

Jadual 3 menunjukkan terdapat kesahan membeza antara faktor berdasarkan nilai punca kuasa dua AVE lebih besar berbanding nilai korelasi faktor dengan faktor lain (Hair et. al, 2010; Fornell \& Lacker, 1981). Faktor motivasi kerja berbeza dengan faktorfaktor lain kerana nilai punca kuasa AVEnya pada .87 melebihi nilai korelasi faktor motivasi kerja dengan pengalaman kerja yang 
bermakna (.53), signifikasi tugas (.63), pengetahuan sebenar hasil kerja (.60) dan pengalaman kebertanggungjawaban terhadap hasil kerja (.57).

Jadual 3

Kesahan Membeza Lima Pemboleh Ubah Kajian

\begin{tabular}{llllll}
\hline \multicolumn{1}{c}{ Faktor } & MK & PM & ST & PS & PB \\
\hline MK & .87 & - & - & - & - \\
PM & .53 & .87 & - & - & - \\
ST & .63 & .41 & .78 & - & - \\
PS & .60 & .38 & .53 & .78 & - \\
PB & .57 & .34 & .61 & .47 & .81 \\
\hline
\end{tabular}

Nota $:$ ST $=$ Signifikasi tugas; $\mathrm{PM}=$ Pengalaman kerja yang bermakna; $\mathrm{PB}=$ Pengalaman kebertanggungjawaban terhadap hasil kerja; PS = Pengetahuan sebenar hasil kerja; $\mathrm{MK}=$ Motivasi kerja

\section{Kesahan Nomologikal}

Jadual 4 menunjukkan kesahan nomologikal yang dinilai berasaskan nilai korelasi antara pemboleh ubah kajian. Hubungan setiap pemboleh ubah kajian yang signifikan dan mengikut arah cadangan JCT yang mendasari kajian ini menunjukkan wujud kesahan nomologikal bagi setiap pemboleh ubah yang dikaji (Hair et. al, 2010). Nilai korelasi keseluruhan antara pemboleh ubah kajian adalah antara .34 hingga .63 , nilai ini boleh diterima kerana $<.90$ yang menunjukkan tidak wujud masalah multikolineariti antara pemboleh ubah kajian (Hair et.al, 2010)

\section{Kesahan Pemodelan Persamaan Struktur Lima Pemboleh Ubah Kajian}

Rajah 2 menunjukkan model yang terjana bagi pemodelan persamaan struktur lima pemboleh ubah kajian. Kesahan pemodelan persamaan struktur ditentu berdasarkan perbandingan ketepatan padanan dengan model pengukuran keseluruhannya (Hair et. al, 2010). Pemodelan persamaan struktur dibina dengan menukarkan kovarian yang disahkan dalam model pengukuran keseluruhan kepada laluan antara pemboleh ubah. Terdapat satu pemboleh ubah eksogenus 
dalam model ini, iaitu signifikasi tugas kemahiran (ST). Secara pratiknya, ia menunjukkan tidak terdapat hipotesis yang dapat meramal pemboleh ubah ini. Model ini juga turut mengandungi empat pemboleh ubah endogenus terdiri daripada pengalaman kerja yang bermakna (PM), pengalaman kebertanggungjawaban terhadap hasil kerja (PB), pengetahuan sebenar hasil kerja (PS) dan motivasi kerja guru (MK).

Jadual 4

Kesahan Nomologikal Lima Pemboleh Ubah Kajian

\begin{tabular}{clccccc}
\hline Bil & Faktor & ST & PM & PB & PS & MK \\
\hline $\mathbf{1}$ & ST & 1 & - & - & - & - \\
$\mathbf{2}$ & PM & $.41 * * *$ & 1 & - & - & - \\
$\mathbf{3}$ & PB & $.61 * * *$ & $.34 * * *$ & 1 & - & - \\
$\mathbf{4}$ & PS & $.53 * * *$ & $.38 * * *$ & $.47 * * *$ & 1 & - \\
$\mathbf{5}$ & MK & $.63 * * *$ & $.53 * * *$ & $.57 * * *$ & $.60 * * *$ & 1 \\
\hline
\end{tabular}

Nota: $* * * p<.001 ; \mathrm{ST}=$ Signifikasi tugas; $\mathrm{PM}=$ Pengalaman kerja yang bermakna; $\mathrm{PB}=$ Pengalaman kebertanggungjawaban terhadap hasil kerja; PS = Pengetahuan sebenar hasil kerja; MK = motivasi kerja

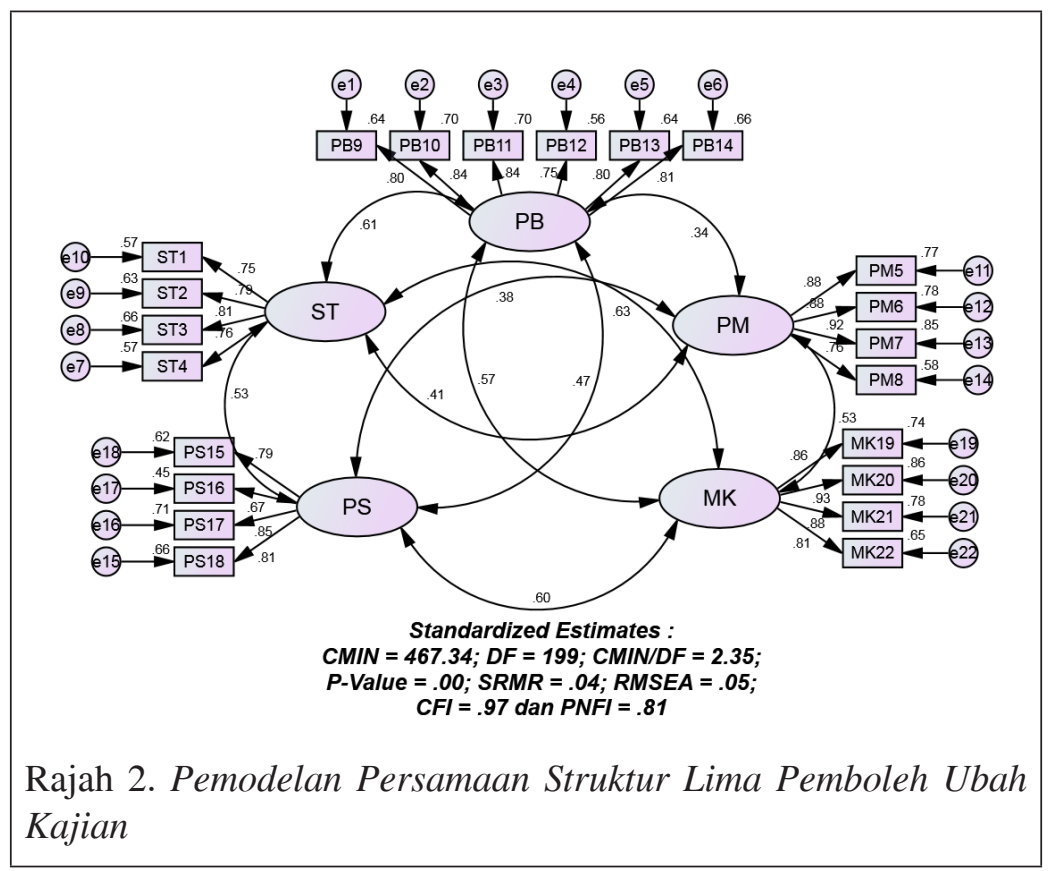


Nota: ST = Signifikasi tugas; $\mathrm{PM}=$ Pengalaman kerja yang bermakna; $\mathrm{PB}=$ Pengalaman kebertanggungjawaban terhadap hasil kerja; PS = Pengetahuan sebenar hasil kerja; $\mathrm{MK}=$ Motivasi kerja

Jadual 5 menunjukkan analisis pemodelan persamaan struktur yang terjana mencapai tahap kesepadanan yang baik $(\mathrm{CMIN}=498.15$, $\mathrm{DF}=202, \mathrm{CMIN} / \mathrm{DF}=2.47, p=.00, \mathrm{SRMR}=.06, \mathrm{RMSEA}=$ $.05, \mathrm{CFI}=.96$ dan PNFI $=.82$ ). Perbandingan ketepatan padanan antara pemodelan persamaan struktur yang terjana dengan model pengukurannya menunjukkan tidak terdapat perbezaan yang ketara. Namun perbandingan petunjuk CMIN, DF, CMIN/DF, SRMR dan CFI menunjukkan pemodelan persamaan struktur yang terjana mencapai ketepatan padanan yang lebih baik berbanding model pengukuran akhirnya (Hair et.al, 2010).

Jadual 5

Perbandingan Tahap Kesepadanan Model Persamaan Struktur Dengan Model Pengukuran Keseluruhan

\begin{tabular}{lccc}
\hline \multicolumn{1}{c}{ Petunjuk } & $\begin{array}{c}\text { Nilai } \\
\text { Petunjuk } \\
\text { Diterima }\end{array}$ & $\begin{array}{c}\text { Model } \\
\text { Pengukuran } \\
\text { Keseluruhan }\end{array}$ & $\begin{array}{c}\text { Model } \\
\text { Persamaan } \\
\text { Struktur }\end{array}$ \\
\hline Absolute Fit Indices & & & \\
CMIN $\left(\chi^{2}\right)$ & - & 467.34 & 498.15 \\
DF & - & 199 & 202 \\
CMIN/DF & $<.03$ & 2.35 & 2.47 \\
PROB (P-Val) & $>.05$ & .00 & .00 \\
SRMR & $<.08$ & .04 & .06 \\
RMSEA & $<.08$ & .05 & .05 \\
Incremental Fit Indices & & & \\
CFI & $>.90$ & .97 & .96 \\
Parsimony Fit Indices & & & .82 \\
PNFI & $>.60$ & .81 & \\
\hline
\end{tabular}

\section{DAPATAN KAJIAN}

\section{Objektif Satu: Kesan langsung signifikasi tugas terhadap} pengalaman psikologi

Jadual 6 menunjukkan analisis bootstrap AMOS 21 bagi kesan langsung signifikasi tugas terhadap pengalaman psikologi terdiri daripada pengalaman kerja yang bermakna, pengalaman 
kebertanggungjawaban terhadap hasil kerja dan pengetahuan sebenar hasil kerja. Dapatan kajian menunjukkan signifikasi tugas memberi kesan langsung yang signifikan dan positif terhadap pengalaman kerja yang bermakna $(\beta=.44, p=.00$, BC 95\% CI $[.37, .50]$, pengalaman kebertanggungjawaban terhadap hasil kerja $(\beta=.63, p=.00, \mathrm{BC} 95 \%$ CI $[.57, .68]$ dan pengetahuan sebenar hasil kerja $(\beta=.56, p=.00, \mathrm{BC} 95 \%$ CI $[.49, .62]$. Dapatan ini menjelaskan peningkatan 1 unit tahap signifikasi tugas menyebabkan berlaku peningkatan secara langsung dalam pengalaman kerja yang bermakna, pengalaman kebertanggungjawaban terhadap hasil kerja dan pengetahuan sebenar hasil kerja dengan masing-masing pada 44 unit, 63 unit dan 56 unit.

Jadual 6

Kesan langsung signifikasi tugas terhadap pengalaman psikologi

\begin{tabular}{|c|c|c|c|c|c|c|c|c|}
\hline & \multicolumn{4}{|c|}{ Unstandardized } & \multicolumn{4}{|c|}{ Standardized } \\
\hline & \multicolumn{4}{|c|}{ Bootstrap BC $95 \%$ CI } & \multicolumn{4}{|c|}{ Bootstrap BC $95 \%$ CI } \\
\hline & $\begin{array}{c}\text { B-EST } \\
(\mathrm{SE})\end{array}$ & Bawah & Atas & $P$ & $\begin{array}{c}\text { B-EST } \\
(\mathrm{SE})\end{array}$ & Bawah & Atas & $P$ \\
\hline ST à PM & $\begin{array}{c}.76 \\
(.09)\end{array}$ & .62 & .92 & $.00 * * *$ & $\begin{array}{c}.44 \\
(.04)\end{array}$ & .37 & .50 & $.00 * * *$ \\
\hline ST à PB & $\begin{array}{c}.84 \\
(.07)\end{array}$ & .73 & .96 & $.00 * * *$ & $\begin{array}{c}.63 \\
(.03)\end{array}$ & .57 & .68 & $.00 * * *$ \\
\hline ST à PS & $\begin{array}{c}.98 \\
(.10)\end{array}$ & .83 & 1.17 & $.00 * * *$ & $\begin{array}{c}.56 \\
(.04)\end{array}$ & .49 & .62 & $.00 * * *$ \\
\hline
\end{tabular}

Nota : $* * * p<.001 ; \mathrm{B}-\mathrm{EST}=$ Bootstrap estimates $($ anggaran bootstrap); $\mathrm{SE}=$ Standard error (ralat piawai); $\mathrm{BC}=$ Bias corrected (bias diperbetulkan); $\mathrm{CI}=$ Confident interval (selang keyakinan); ST = Signifikasi tugas; $\mathrm{PM}=$ Pengalaman kerja yang bermakna; $\mathrm{PB}=$ Pengalaman kebertanggungjawaban terhadap hasil kerja; PS = Pengetahuan sebenar hasil kerja

\section{Objektif Dua : Kesan langsung pengalaman psikologi terhadap motivasi kerja guru}

Jadual 7 menunjukkan analisis bootstrap AMOS 21 bagi kesan langsung pengalaman psikologi terhadap motivasi kerja guru. Dapatan kajian menunjukkan pengalaman kerja yang bermakna $(\beta=.25, \mathrm{p}=.00$, BC 95\% CI $[.18, .32]$, pengalaman kebertanggungjawaban terhadap hasil kerja $(\beta=.20, \mathrm{p}=.00, \mathrm{BC}$ 
$95 \%$ CI $[.12, .27]$ dan pengetahuan sebenar hasil kerja $(\beta=.28, \mathrm{p}=$ .00 , BC 95\% CI $[.19, .35]$ memberi kesan langsung yang signifikan serta positif terhadap motivasi kerja guru. Dapatan ini menjelaskan peningkatan pengalaman kerja yang bermakna, pengalaman kebertanggungjawaban terhadap hasil kerja dan pengetahuan sebenar hasil kerja menyebabkan motivasi kerja guru meningkat.

Jadual 7

Hubungan langsung pengalaman psikologi dengan motivasi kerja guru

\begin{tabular}{lcccccccc}
\hline & \multicolumn{3}{c}{ Unstandardized } & \multicolumn{5}{c}{ Standardized } \\
\cline { 2 - 9 } & \multicolumn{3}{c}{ Bootstrap BC 95\% CI } & \multicolumn{5}{c}{ Bootstrap BC 95\% CI } \\
\cline { 2 - 9 } & $\begin{array}{c}\text { B-EST } \\
\text { (SE) }\end{array}$ & Bawah & Atas & $P$ & $\begin{array}{c}\text { B-EST } \\
\text { (SE) }\end{array}$ & Bawah & Atas & $P$ \\
\hline PM & .25 & .18 & .32 & $.00 * * *$ & .25 & .18 & .32 & $.00 * * *$ \\
& $(.04)$ & & & & $(.04)$ & & & \\
PB & .25 & .16 & .35 & $.00 * * *$ & .20 & .12 & .27 & $.00 * * *$ \\
& $(.06)$ & & & & $(.05)$ & & & \\
PS & .27 & .19 & .35 & $.00 * * *$ & .28 & .19 & .35 & $.00 * * *$ \\
& $(.05)$ & & & & $(.05)$ & & & \\
\hline
\end{tabular}

Nota $: * * * p<.001 ; \mathrm{B}-\mathrm{EST}=$ Bootstrap estimates $($ anggaran bootstrap $) ; \mathrm{BC}=$ Bias corrected (bias diperbetulkan); $\mathrm{CI}=$ Confident interval (selang keyakinan); $\mathrm{PM}$ = Pengalaman kerja yang bermakna; $\mathrm{PB}=$ Pengalaman kebertanggungjawaban terhadap hasil kerja; PS = Pengetahuan sebenar hasil kerja

\section{Objektif Tiga: Kesan langsung dan tak langsung signifikasi tugas terhadap motivasi kerja guru.}

Jadual 8 menunjukkan analisis kesan pengantaraan pelbagai dengan menggunakan analisis regresi PROCESS MACRO IBM SPSS 21 bagi menentukan kesan langsung dan tak langsung signifikasi tugas terhadap motivasi kerja guru. Analisis menunjukkan signifikasi tugas memberi kesan langsung yang signifikan dan positif $(\beta=.52, t$ $=7.11, \mathrm{BC} 95 \%$ CI $[.37, .66]$ terhadap motivasi kerja guru. Dapatan ini menjelaskan peningkatan tahap signifikasi tugas menyebabkan peningkatan berlaku dalam motivasi kerja guru. Peningkatan 1 unit tahap signifikasi tugas menyebabkan peningkatan motivasi kerja guru sebanyak 52 unit. 
Sementara itu, analisis selang keyakinan 95\% bias diperbetulkan bagi kesan tak langsung menunjukkan pengalaman kerja yang bermakna ( $\beta=.20, \mathrm{t}=6.41$, BC 95\% CI $[.14, .26]$, pengalaman kebertanggungjawaban terhadap hasil kerja $(\beta=.21, \mathrm{t}=4.51, \mathrm{BC}$ $95 \%$ CI $[.13, .29]$ dan pengetahuan sebenar hasil kerja $(\beta=.31, \mathrm{t}=$ 7.36 , BC 95\% CI $[.23, .40]$ tidak mengandungi nilai sifar. Dengan nilai kesan langsung berbeza daripada sifar dan signifikan $(\beta=.52, t$ $=7.11, \mathrm{BC} 95 \% \mathrm{CI}[.37, .66]$ serta mempunyai arah hubungan yang positif sebagaimana kesan tak langsung menunjukkan pengalaman kerja yang bermakna, pengalaman kebertanggungjawaban terhadap hasil kerja dan pengetahuan sebenar hasil kerja berperanan sebagai pengantara separa bagi kesan tak langsung signifikasi tugas terhadap motivasi kerja guru.

Perbandingan nisbah kesan menunjukkan pengetahuan sebenar hasil kerja memberi kesan pengantaraan yang lebih kuat (nisbah kesan = .25) berbanding pengalaman kebertanggungjawaban terhadap hasil kerja (nisbah kesan $=.17$ ) dan pengalaman kerja yang bermakna (nisbah kesan $=.16$ ) bagi kesan tak langsung antara signifikasi tugas terhadap motivasi kerja guru. Dapatan ini menjelaskan bahawa sisihan piawai (standard deviation) motivasi kerja guru meningkat sebanyak .25 unit apabila berlaku peningkatan satu unit dalam sisihan piawai signifikasi tugas melalui pengetahuan sebenar hasil kerja. Sementara masing-masing sisihan piawai motivasi kerja guru meningkat sebanyak .17 dan .16 unit apabila berlaku peningkatan satu unit sisihan piawai signifikasi tugas melalui pengalaman kebertanggungjawaban terhadap hasil kerja dan pengalaman kerja yang bermakna.

Jadual 8

Kesan langsung dan tak langsung signifikasi tugas terhadap motivasi kerja guru

\begin{tabular}{lcccccc}
\hline & Anggaran & \multicolumn{2}{c}{ Nilai Koefisien } & \multicolumn{3}{c}{ BC 95\% CI } \\
\cline { 3 - 7 } & Nilai & SE & $\boldsymbol{t}$ & Bawah & Atas & $\boldsymbol{P}$ \\
\hline Kesan keseluruhan & 1.22 & .06 & 21.19 & 1.11 & 1.34 & $.00 * * *$ \\
Kesan langsung & .52 & .07 & 7.11 & .37 & .66 & $.00 * * *$ \\
\hline
\end{tabular}




\begin{tabular}{|c|c|c|c|c|c|c|}
\hline & \multirow{2}{*}{$\begin{array}{c}\text { Anggaran } \\
\text { Nilai }\end{array}$} & \multicolumn{2}{|c|}{ Nilai Koefisien } & \multicolumn{2}{|c|}{ BC $95 \%$ CI } & \multirow[b]{2}{*}{$P$} \\
\hline & & SE & $t$ & Bawah & Atas & \\
\hline \multicolumn{7}{|c|}{ Kesan tak langsung } \\
\hline $\mathbf{P M}$ & .20 & .03 & 6.41 & .14 & .26 & $.00 * * *$ \\
\hline PB & .21 & .05 & 4.51 & .13 & .29 & $.00 * * *$ \\
\hline PS & .31 & .04 & 7.36 & .23 & .40 & $.00 * * *$ \\
\hline Jumlah & .71 & .06 & - & .60 & .83 & - \\
\hline \multicolumn{7}{|c|}{ Ratio of indirect to total effect } \\
\hline PM & .16 & .03 & - & .11 & .22 & - \\
\hline PB & .17 & .04 & - & .10 & .24 & - \\
\hline PS & .25 & .04 & - & .19 & .33 & - \\
\hline Jumlah & .58 & .05 & - & .49 & .68 & - \\
\hline
\end{tabular}

\section{PERBINCANGAN}

Kajian ini adalah untuk menilai peranan signifikasi tugas dan pengalaman psikologi terdiri daripada pengalaman kerja yang bermakna, pengalaman kebertanggungjawaban terhadap hasil kerja dan pengetahuan sebenar hasil kerja dalam menerangkan motivasi kerja guru. Kajian ini juga menjelaskan kesan langsung dan tak langsung signifikasi tugas, pengalaman kerja yang bermakna, pengalaman kebertanggungjawaban terhadap hasil kerja dan pengetahuan sebenar hasil kerja terhadap motivasi kerja guru dalam satu kajian serta diuji secara serentak. Di samping itu, kajian ini turut memperkenalkan model yang menjelaskan kepentingan signifikasi tugas, pengalaman kerja yang bermakna, pengalaman kebertanggungjawaban terhadap hasil kerja dan pengetahuan sebenar hasil kerja sebagai penyumbang yang signifikan kepada motivasi kerja guru.

\section{a) Kesan langsung signifikasi tugas terhadap pengalaman psikologi}

Signifikasi tugas dalam rangka kerja pengajaran mempunyai kesan langsung yang signifikan dengan pengalaman kerja yang 
bermakna, pengalaman kebertanggungjawaban terhadap hasil kerja dan pengetahuan sebenar hasil kerja. Hal ini secara langsung menunjukkan apabila rangka kerja pengajaran menyediakan peluang kepada guru untuk merasai impak positif hasil daripada pelaksanaan pengajaran kepada kehidupan orang seperti pelajar, masyarakat dan pembangunan negara, ia memberi pengaruh yang positif terhadap pengalaman psikologi guru. Guru merasai bahawa pengajaran yang dilakukan amat bermakna dan setiap perkara yang dilakukan dalam proses pengajaran dianggap bermanfaat. Dapatan ini konsisten dengan JCT yang mencadangkan sekiranya sesuatu rangka kerja mempunyai ciri signifikasi tugas, pengalaman kerja bermakna lebih mudah dialami oleh pekerja (Hackman \& Oldham, 1980). Di samping turut menyokong pandangan Bessette (2003), Kristensen et. al (2005) yang menekankan pengalaman kerja bermakna sebagai persepsi positif pekerja secara dalaman terhadap kerja yang menjadi keperluan asas untuk mencari tujuan utama dalam melakukan kerja dan terhasil daripada interaksi positif antara pekerja dengan organisasi kerja serta rangka kerja. Dapatan ini juga selaras dengan analisis meta oleh Behson (2012) dan Humphrey et. al (2007) yang menunjukkan kehadiran ciri signifikasi tugas dalam sesuatu rangka kerja yang disediakan oleh sesebuah organisasi secara signifikan dan positif mempengaruhi secara langsung pengalaman kerja yang bermakna.

Kesan daripada kewujudan ciri signifikasi tugas dalam rangka kerja pengajaran juga menyebabkan guru mempunyai perasaan kebertanggungjawaban terhadap hasil pengajaran, sedia penerimaan penghargaan atau dipersalahkan untuk setiap hasil pengajaran yang dilakukan dan guru lebih mengambil berat tentang pelaksanaan pengajaran sama ada telah dilakukan dengan baik atau sebaliknya. Walau bagaimanapun dapatan ini tidak konsisten dengan cadangan JCT yang mengandaikan signifikasi tugas tidak mempunyai hubungan langsung yang signifikan dengan pengalaman kebertanggungjawaban terhadap hasil kerja (Hackman \& Oldham, 1980). Dapatan ini menjelaskan secara langsung bahawa perasaan kebertanggungjawaban merupakan salah satu faktor penting yang mempengaruhi keberhasilan proses pengajaran dan pembelajaran (Dahlgren \& Hammar, 2009; Lauermann \& Karabenick, 2011, 2013). Perasaan kebertanggungjawaban menjelaskan rasa dalaman dan komitmen guru untuk menyumbang kepada keberhasilan 
matlamat pengajaran dan mempertahankan keberhasilan matlamat tersebut (Lauermann \& Karabenick, 2011). Perasaan kebertanggungjawaban melibatkan perasaan guru terhadap amalan pengajaran, pembelajaran pelajar dan prestasi pelajar (Lauermann \& Karabenick, 2013). Oleh itu, pelaksanaan pengajaran memerlukan guru memahami secara mendalam tentang tanggungjawab mereka dan situasi yang memerlukan mereka bertanggungjawab secara peribadi untuk setiap hasil kerja yang dilakukan (Lauermann \& Karabenick, 2013). Namun begitu, kajian ini konsisten dengan analisis meta yang menunjukkan di samping mempunyai hubungan langsung yang signifikan dengan pengalaman kerja yang bermakna, signifikasi tugas turut mempunyai hubungan yang signifikan dengan pengalaman kebertanggungjawaban terhadap hasil kerja (Behson, 2012; Humphrey et. al, 2007).

Selain itu, kehadiran signifikasi tugas dalam rangka kerja pengajaran telah menyebabkan guru lebih mengetahui sama ada pengajaran telah dilakukan secara memuaskan atau tidak dan tidak berdepan dengan masalah untuk mengetahui sama ada pengajaran telah dilaksanakan dengan baik atau tidak. Dapatan ini turut tidak menyokong saranan JCT yang mengandaikan signifikasi tugas dalam sesuatu rangka kerja tidak mempengaruhi secara signifikan pengetahuan sebenar hasil kerja (Hackman \& Oldham, 1980). Dapatan ini mungkin menjelaskan tentang individu guru sebagaimana pandangan Dewey (1933), iaitu individu yang mempunyai pengetahuan sebenar hasil kerja sentiasa aktif dalam memikirkan masalah yang dihadapi, gigih mencari jalan penyelesaian, sedia mengorbankan masa untuk memastikan masalah yang dihadapi dapat diatasi dan sentiasa menerima pandangan yang berpotensi untuk menyelesaikan masalah, namun memerlukan kajian lanjut dilakukan. Walaupun tidak konsisten dengan JCT, dapatan kajian ini selaras dengan kajian Behson (2012) dan Humphrey et. al (2007) yang menunjukkan signifikasi tugas dalam rangka kerja mempengaruhi secara signifikan pengetahuan sebenar hasil kerja.

Kajian ini menunjukkan pengalaman psikologi terdiri daripada pengalaman kerja yang bermakna, pengalaman kebertanggungjawaban terhadap hasil kerja dan pengetahuan sebenar hasil kerja dipengaruhi secara signifikan positif oleh signifikasi tugas dalam rangka kerja pengajaran. Sehubungan dengan itu, bagi meningkatkan pengalaman psikologi dalam kalangan guru, 
kepimpinan pendidikan di sekolah perlu bijak memanipulasikan faktor signifkasi tugas dalam reka bentuk rangka kerja pengajaran untuk menghasilkan kesan positif kepada guru dalam melaksanakan pengajaran di sekolah.

\section{b) Kesan langsung pengalaman psikologi Terhadap motivasi kerja guru}

Kajian ini memfokuskan kepada tiga pemboleh ubah pengalaman psikologi sebagaimana disarankan oleh JCT terdiri daripada pengalaman kerja yang bermakna, pengalaman kebertanggungjawaban terhadap hasil kerja dan pengetahuan sebenar hasil kerja (Hackman \& Oldham, 1980). Ketiga-tiga pemboleh ubah pengalaman psikologi ini dipilih kerana ia paling tepat bagi menjelaskan proses motivasi kerja mengikut perspektif JCT. Ketiga-tiga pengalaman psikologi ini juga digunakan dalam kajian-kajian motivasi kerja menggunakan perspektif JCT (Behson, 2012; Shani \& AnandKumar, 2011; Humphrey et. al, 2007; Behson, Eddy \& Lorenzat, 2000; Renn \& Vandenberg, 1995).

Dapatan kajian ini menunjukkan ketiga-tiga pemboleh ubah pengalaman psikologi mempunyai hubungan yang signifikan dengan motivasi kerja guru. Dapatan ini juga menjelaskan terdapat pengaruh yang positif antara pengalaman kerja yang bermakna, pengalaman kebertanggungjawaban terhadap hasil kerja dan pengetahuan sebenar hasil kerja dengan motivasi kerja guru. Keputusan ini menjelaskan apabila guru mempunyai perasaan bahawa pengajaran yang dilakukan adalah bermakna, rasa kebertanggungjawaban yang tinggi terhadap hasil pengajaran dan pengetahuan yang tinggi tentang hasil sebenar pengajaran mereka menyebabkan motivasi kerja guru dalam melaksanakan pengajaran meningkat. Motivasi ini dijelaskan melalui peningkatan kepuasan dan pandangan terhadap diri sendiri apabila pengajaran dapat dilaksanakan dengan baik. Di samping itu, kegembiraan guru meningkat apabila mengetahui pengajaran mereka dapat dilaksanakan dengan baik dan perasaan guru boleh terjejas apabila pengajaran gagal dilaksanakan dengan baik. Perasaan ini mendorong guru untuk terus melaksanakan pengajaran dengan lebih baik pada masa depan. Hasil kajian ini konsisten dengan JCT yang mencadangkan peningkatan dalam pengalaman psikologi secara positif menyebabkan peningkatan dalam motivasi kerja (Hackman \& Oldham, 1980). 
Hasil kajian secara umumnya konsisten dengan kajian yang dilakukan dalam kalangan jururawat Hospital Estonian dan kakitangan perbankan di Coimbatore, Tamil Nadu, India yang menunjukkan pengalaman psikologi mempunyai pengaruh yang signifikan dan positif dengan motivasi kerja (Toode et. al, 2014; Shani \& AnandKumar, 2011). Kajian ini mendapati pengetahuan sebenar hasil kerja mempunyai hubungan yang lebih kuat dengan motivasi kerja berbeza dengan kajian Toode et. al yang menunjukkan pengalaman kerja yang bermakna mempunyai hubungan yang lebih kuat dengan motivasi kerja. Sebaliknya kajian Shani dan AnandKumar menunjukkan pengalaman kebertanggungjawaban terhadap hasil kerja mempunyai hubungan yang lebih kuat dengan motivasi kerja. Dapatan kajian ini mengesahkan lagi bahawa kekuatan hubungan antara pengalaman psikologi dengan motivasi kerja adalah berbeza mengikut sampel kajian.

Kajian ini mendapati motivasi kerja guru dipengaruhi secara signifikan dan positif oleh ketiga-tiga pemboleh ubah pengalaman psikologi. Hal ini menjelaskan untuk meningkatkan motivasi kerja, guru perlu meningkatkan tahap pengalaman kerja yang bermakna, pengalaman kebertanggungjawaban terhadap hasil kerja dan pengetahuan sebenar hasil kerja. Hal selari dengan pandangan JCT, iaitu ketiga-tiga pengalaman psikologi perlu dialami oleh pekerja untuk meningkatkan motivasi kerja (Hackman \& Oldham, 1980).

\section{c) Kesan langsung dan tak langsung signifikasi tugas terhadap motivasi kerja guru}

Kajian ini mendapati signifikasi tugas memberi kesan langsung yang signifikan dan positif terhadap motivasi kerja. Hal ini menjelaskan apabila guru menyedari pengajaran yang dilakukan boleh memberi kesan kepada kehidupan orang terutamanya pelajar, masyarakat dan pembangunan negara, motivasi kerja guru boleh meningkat. Peningkatan motivasi ini berlaku melalui peningkatan rasa kepuasan dan pandangan terhadap diri sendiri apabila pengajaran dapatan dilakukan dengan baik. Guru merasa kurang gembira apabila pengajaran gagal dilaksanakan dengan baik dan setiap prestasi pelaksanaan pengajaran boleh mempengaruhi perasaan guru. Kekuatan impak positif tentang kepentingan pengajaran menyebabkan guru sentiasa berusaha untuk melaksanakan 
pengajaran dengan baik. Walau bagaimanapun dapatan ini gagal menyokong saranan JCT yang mencadangkan peningkatan motivasi kerja oleh signifikasi tugas hanya berlaku melalui proses pengantaraan pengalaman kerja yang bermakna dan tidak terdapat hubungan langsung antara signifikasi tugas dengan motivasi kerja (Hackman \& Oldham, 1980). Namun menyokong kajian-kajian yang mengabaikan pengalaman psikologi dalam kerangka konseptual yang mendapati signifikasi tugas mempunyai hubungan langsung yang signifikan dan positif dengan motivasi kerja (Isfahani et. al, 2013; Gomes et. al, 2013; Nadeem et. al, 2013; Azash et al, 2012; Aneel et. al, 2011; Hala \& Neamat, 2012; Abu Zafar et. al, 2013; Casey et. al, 2012b; Rabia \& Adnan, 2010; Mahesh, 2010).

Sementara itu, analisis kajian mendapati pengalaman kerja yang bermakna memberi kesan pengantara separa yang signifikan dan positif bagi kesan tak langsung signifikasi tugas terhadap motivasi kerja guru. Pengalaman kerja yang bermakna berperanan sebagai pengantara separa kerana kesan langsung signifikasi tugas terhadap motivasi kerja guru adalah signifikan apabila model diuji secara serentak dengan pengalaman kerja yang bermakna dan arah hubungannya adalah sama dengan hubungan tak langsung signifikasi tugas dengan motivasi kerja guru. Kesan pengantaraan separa menjelaskan bahawa kekuatan kesan tak langsung antara signifikasi tugas dengan motivasi kerja bukan hanya dipengaruhi oleh pengalaman kerja yang bermakna tetapi turut dipengaruhi oleh pengalaman kebertanggungjawaban terhadap hasil kerja dan pengetahuan sebenar hasil kerja. Dapatan ini bertentangan dengan JCT yang mencadangkan hanya pengalaman kerja yang bermakna berperanan sebagai pengantara bagi kesan tak langsung signifikasi tugas terhadap motivasi kerja (Hackman \& Oldham, 1980).

Justeru, kajian ini mencadangkan agar tahap signifikasi tugas dalam rangka kerja pengajaran guru diberi perhatian kerana pemboleh ubah ini dianggap penting dalam meningkatkan pengalaman psikologi guru seterusnya meningkatkan motivasi kerja guru untuk melaksanakan pengajaran. Kajian ini juga mencadangkan agar persekitaran pengajaran yang boleh meningkatkan tahap signifikasi tugas sentiasa dipupuk dan dibangunkan supaya motivasi kerja guru dapat ditingkatkan. 


\section{IMPLIKASI}

Kajian ini mengembangkan Job Characteristics Theory (JCT) dalam konteks rangka kerja pengajaran guru. Kajian ini dari satu aspek berjaya menyokong JCT terutama hubungan langsung signifikasi tugas dengan pengalaman kerja yang bermakna dan pengalaman psikologi dengan motivasi kerja. Namun dari satu aspek lain, kajian ini berjaya mengembangkan JCT apabila signifikasi tugas turut mempengaruhi secara langsung pengalaman kebertanggungjawaban terhadap hasil kerja dan pengetahuan sebenar hasil kerja dalam menghasilkan pengaruh yang besar terhadap peningkatan motivasi kerja guru. JCT menjelaskan hanya pengalaman kerja yang bermakna memberi kesan pengantaraan bagi hubungan tak langsung signifikasi tugas dengan motivasi kerja guru. Sebaliknya kajian ini membuktikan pengalaman kebertanggungjawaban terhadap hasil kerja dan pengetahuan sebenar hasil kerja turut berperanan sebagai pengantara bagi hubungan tak langsung signifikasi tugas dengan motivasi kerja guru. Selain itu, signifikasi tugas dalam rangka kerja pengajaran turut mempunyai hubungan langsung dengan motivasi kerja dan menjadi penentu secara langsung kepada peningkatan motivasi kerja guru. Oleh itu, signifikasi tugas dalam rangka kerja pengajaran boleh dimanipulasikan secara langsung untuk meningkatkan motivasi kerja guru tanpa bergantung pada proses mengalami ketiga-tiga pengalaman psikologi yang dicadangkan.

Kajian ini juga membuktikan ketiga-tiga pemboleh ubah pengalaman psikologi berperanan sebagai pengantara separa antara hubungan signifikasi tugas dengan motivasi kerja guru. Model struktural yang dicadangkan dalam kajian ini dapat menjelaskan isu rangka kerja pengajaran berasaskan faktor signifikasi tugas dan pengalaman psikologi serta mencadangkan langkah-langkah yang perlu diambil oleh kepimpinan pendidikan untuk meningkatkan tahap motivasi kerja guru dalam melaksanakan pengajaran di sekolah.

\section{CADANGAN}

Kajian ini hanya melibatkan guru sekolah menengah kebangsaan harian biasa di negeri Kedah. Bagi kajian lanjutan dicadangkan agar melibatkan semua guru yang berkhidmat di negeri Kedah 
agar pola motivasi kerja guru berasaskan rangka kerja pengajaran dapat dirumuskan. Dalam kajian ini, kaedah kuantitatif telah diaplikasi sepenuhnya. Oleh itu, kajian lanjutan dicadangkan turut menggunakan kaedah kualitatif melalui pemerhatian, temu bual atau kumpulan fokus bagi memperoleh maklumat yang lebih lengkap untuk menyokong dapatan kajian. Selain itu, penggunaan kaedah yang pelbagai boleh membantu mengenal pasti faktor lain yang turut membina rangka kerja pengajaran dan turut mempengaruhi motivasi kerja guru.

\section{KESIMPULAN}

Kajian ini telah menguji model yang menggabungkan signifikasi tugas, pengalaman psikologi dan motivasi kerja guru. Model yang dicadangkan telah dapat menjelaskan hubungan antara semua pemboleh ubah yang dikaji dalam konteks guru sekolah menengah kebangsaan harian biasa di negeri Kedah dengan berasaskan rangka kerja pengajaran guru. Dalam kajian ketiga-tiga pengalaman psikologi didapati boleh dipengaruhi oleh signifikasi tugas dalam rangka kerja pengajaran dan seterusnya mempengaruhi motivasi kerja guru. Pengalaman psikologi berperanan sebagai pengantara yang baik kerana memberi kesan positif terhadap motivasi kerja guru. Dapatan kajian ini mencadangkan agar kepimpinan pendidikan memberi tumpuan kepada usaha meningkatkan ciri signifikasi tugas dalam rangka kerja pengajaran manakala guru-guru disarankan agar peka kepada persekitaran pengajaran yang boleh meningkatkan tahap pengalaman psikologi. Kajian ini menyumbang kepada kefahaman tentang pengaruh rangka kerja terhadap motivasi kerja, di samping mengembangkan kerangka Job Characteristics Theory (JCT) dalam kajian motivasi kerja berasaskan rangka kerja.

\section{RUJUKAN}

Abu Bakar Nordin \& Ikhsan Othman. (2003). Falsafah pendidikan dan kurikulum. Tanjong Malim, Malaysia: Quantum Books. Abu Zafar Ahmed Mukul, Shah Johir Rayhan, Fazlul Hoque \& Faijul Islam. (2013). Job characteristics model of Hackman 
and Oldham in garment sector in Bangladesh : A case study at Savar Area in Dhaka District. International Journal of Finance and Management Sciences, I (4), 188 - 195.

Adebayo, R., \& Ezeanya, I.D. (2010). Effects of job autonomy, task identity and profession on burnout among health worker in Jos, Nigeria. European Journal of Social Science, 14 (1), 116 $-124$.

Ahmad Mahdzan Ayob. (2007). Kaedah penyelidikan sosioekonomi: Edisi ketiga. Kuala Lumpur, Malaysia: Dewan Bahasa dan Pustaka.

Akintoye, I. R. (2000). The place of financial management in personel psychology. A paper presented as part of personnel psychology guest lecture series. Department of Guidance and Counselling, University of Ibadan, Ibadan.

Aneel Kumar, Qaisar Abas, Ikhtiar Ali Ghumro, \& Ashi Zaeshan. (2011). Job characteristic as predictors of job satisfaction and motivation. Asian Journal of Business and Management Science, 1 (4), 206 - 216.

Azash, S.M., Safare, R., Thirupalu, N., \& Subhan, B. (2012). Job characteristic as predictors of work motivation and job satisfaction on bank employees. International Journal of Business and Management Tomorrow, 2 (1), 1 - 7.

Babbie, E. (2008). The basics of social research (4th ed.). Belmont, CA: Thomson Wadsworth.

Bessette, J. L. (2003). Meaningful work: A study of human resources professionals in the nevada gaming industry. Reno, US: University of Nevada.

Behson, S. J., Eddy, E. R., \& Lorenzet, S. J. (2000). The importance of the critical psychological states in the job characteristic model: A meta analytic and structural equation modelling examination. Current Research in Social Psychology, 5 (9), $170-189$.

Behson, S. J. (2012). Using relative weights to reanalyse research on the job characteristic model. Journal of Organizational Psychology, 12 (2), 71 - 81.

Boud, D., Keogh, R., \& Walker, D. (1985). Reflection: Turning experience into learning. London, UK: Kogan Page.

Brislin, R. W. (1970). Back-translation for cross-culture research. Journal of Cross-Cultural Psychology, 1(3), 185-216. 
Casey, R., \& Robbins, J. (2008). Benefits of high internal work motivation comparing retail sector to manufacturing. Journal of Diversity Management, 3 (3), 13 - 18.

Casey, J. R., Deplas, N., Rossmaier, J., \& Hilton, R. (2012). A test of the Hackman and Oldham model in Nicaragua, Guatemala, Mexico and United States. Retrieved from: http://www. jebejournal.org/index.php/jebe/article/download/8/2.

Champoux, J. E. (2011). Organizational behaviour: Intergrating individuals, groups, and organizations. New York, US: Routlegde Taylor \& Francis Group.

Chua Yan Piaw. (2011). Kaedah penyelidikan edisi kedua. Kuala Lumpur, Malaysia: McGraw-Hill (Malaysia) Sdn. Bhd.

Cohen, L., Manion, L., \& Morrison, K. (2011). Research methods in education 7th edition. New York, US: Routledge Taylor \& Francis Group.

Creswell, J. W. (2012). Educational research: planning, conducting and evaluating quantitative and qualitative research 4th edition. Boston, MA. Pearson Education Inc.

Dahlgren, M. A., \& Hammar C, E. (2009). Learning for professional life: student teachers' and graduated teachers' views of learning, responsibility and collaboration. Teaching and Teacher Education, 25(8), 991-999.

Dewey, J. (1933). How we think. A restatement of the relation of reflective thinking to the educative process. Boston. D.C. Heath and Company.

Faturochman. (1997). The job characteristics theory: A review. Buletin Psikologi, 2, 1-13.

Fornell, C., Larcker, D. F. (1981). Evaluating structural equation models with unobservable variables and measurement error. Journal of Marketing Research 18 (1), 39-50.

Gagne, M., \& Forest, J. (2008). The study of compensation systems through the lens of self determination theory: Reconciling 35 years of debate. Canadian Psychology, 49, 225 - 232. doi: 10.1037/a0012757.

Gay, L. R., \& Diehl, P. L. (1996). Educational research: Competencies for analysis and application (5th ed.). Upper Saddle River, NJ: Prentice-Hall, Inc.

Gomes, D. R., Asseiro, V., \& Ribeiro. (2013). Trigerring employee motivation in adverse organizational contexts: Going the extra mile while holding hands with uncertainty ? Business and Management Research, 2 (1), 41 - 54. 
Hackman, J. R., \& Oldham, G.R. (1975). Development of the job diagnostic survey. Journal of Applied Psychology, 60(2), $159-170$.

Hackman, J. R., \& Oldham, G. R. (1980). Work redesign. Reading, MA: Addison-Wesley.

Hala Gabr, \& Neamat Mohamad. (2012). Job characteristics model to redesign nursing care delivery system in general surgical unit. Academic Research International, 2 (1), 199 - 211.

Hair, J. F., Black, W.C., Babin, B. J., \& Anderson, R. E. (2010). Multivariate data analysis (7th ed). New Jersey, USA: Prentice Hall Inc.

Hayes, A. F. (2009). Beyond Baron and Kenny: Statistical mediation analysis in the new millennium. Communication Monographs, 74 (4), 408 - 420, doi: 10.1080/03637750903310360.

Hayes, A. F., \& Preacher, K. J. (2010). Quantifying and testing indirect effect in simple mediation models when the constituent paths are nonlinear. Multivariate Behavioral Research, 45(4), $627-660$.

Hein, V., Ries, F., Pires, F., Caune, A., Emeljanovas, A., Ekler, J. H., \& Valantiniene, I. (2012). The relationship between teaching styles and motivation to teach among physical education teachers. Journal of Sports Science and Medicine, 11, 123 - 130.

Hobson, A. J., Ashby, P., McIntyre, J., \& Malderez, A. (2010). International approaches to teacher selection and recruitment, OECD Education Working Papers, No. 47, OECD Publishing: doi: $10.1787 / 5 \mathrm{kmbphhh6qmx-en.}$

Humphrey, S. E., Nahrgang, J.D., \& Morgeson, F. P. (2007). Integrating motivational, social and contextual work design features: A meta analytic summary and theoretical extension of the work design literature. Journal of Applied Psychology, 92 (2), $1332-1356$.

Isfahani, S. S., Bahrami, S., \& Torki, S. (2013). Job characteristics perception and intrinsic motivation in medical record department staff. Medical Archives, 67 (1), 51 - 55. doi: 10.5455/medarh.2013.67.

Jabatan Pendidikan Kedah. (2014, April 14). Statistik sekolah, guru \& murid. Dicapai daripada http://jpnkedah.moe.gov.my

Jabatan Perkhidmatan Awam. (2007). Pekeliling perkhidmatan bilangan 7 tahun 2007: Pemberian kenaikan gaji kepada pegawai perkhidmatan awam persekutuan di bawah sistem 
saraan Malaysia (No. Rujukan : JPA (BGE) 262/5/2/1 (1)). Putrajaya, Malaysia : Percetakan Nasional.

Jesus, S.N., \& Lens, W. (2005). An integrated model for the study of teacher motivation. Applied Psychology: An International Review, 54 (1), 119 - 134.

Kementerian Pelajaran Malaysia. (2012). Laporan awal pelan pembangunan pendidikan Malaysia 2013 - 2025. Putrajaya, Malaysia: Kementerian Pelajaran Malaysia.

Kinicki, A., \& Williams, B.K. (2003). Management: A practical introduction. New York, US: McGraw-Hill.

Kline, R.B. (2005). Principles and practice in structural equation modelling (2nd ed.). New York, USA: The Guilford Press.

Kristensen, T.S., Hannerz, H., Hogh, A., \& Borg, V. (2005). The Copenhagen psychosocial questionnaire-a tool for the assessment and improvement of the psychosocial work environment. Scandinavia Journal of Work, Environment and Health, 31 (6), 438 - 449.

Lauermann, F., \& Karabenick, S. A. (2011). Taking teacher responsibility into account (ability): explicatingits multiple components and theoretical status. Educational Psychologist, 46(2), 122-140.

Lauermann, F., \& Karabenick, S. A. (2013). The meaning and measure of teachers' sense of responsibility for educational Outcomes. Teaching and Teacher Education, 30, 13-26

Lawler, E.J., (1983). Cooptation and threats as "divide and rule" tactics. Social Psychology Quaterly, 46, 89 - 98. doi:10.2307/3033845.

Lee-Ross, D. (1996). The attitudes and work motivation of seasonal hotel worker (Unpublished doctoral dissertation). APU, Cambridge.

Mahesh. (2010). A revisit on the application of Hackman and Oldham model in organisation. Global Journal of Finance and Management, 2 (1), 135 - 145.

Mahfuz Judeh. (2012). Assessing the influence of the job characteristics and self efficacy on job performance: A structural equation modelling analysis. European Journal of Social Science, 28 (3), $355-365$.

M. Nur Mustafa, \& Norasmah Othman. (2010). The effect of work motivation on teacher's work performance in Pekan baru Senior High School, Riau Province, Indonesia. Sosiohumanika, 3(2), $259-272$. 
Miller, K. (2003). Conducting cognitive interviews to understand question-response limitations among poorer and less educated respondents. American Journal of Health Behavior, 27 (3), $264-272$.

Mohamad Khairi Othman, \& Asmawati Suhid. (2010). Peranan sekolah dan guru dalam pembangunan nilai pelajar menerusi penerapan nilai murni : Satu sorotan. SEA Journal of General Studies II, 17 - 30 .

Morgeson, F. P., \& Humphrey, S. E. (2006). The work design questionnaire (WDQ): Developing and validating a comprehensive measure for assessing job design and the nature of work. Journal of Applied Psychology, 91, 1321 1339.

Muhamad Ali Embi. (2006). Cabaran melaksanakan sistem saraan berasaskan merit di sektor awam. Kuala Lumpur, Malaysia : Utusan Publications \& Distributors Sdn. Bhd.

Muhamad Ali Embi, \& Syamsir Saili. (2013). Motivasi perkhidmatan awam dalam kalangan negara maju dan membangun. Kuala Lumpur, Malaysia: Institut Terjemahan \& Buku Malaysia.

Nadeem Bhatti, Anwar Ali Shah G. Syed \& F. M. Shaikh. (2012). Job satisfaction and motivation in banking industry in Pakistan. Journal of Asian Business Strategy, 2 (3), 54 - 62.

Nazila Karimi, \& Seyed Ali Siyadat. (2014). Prediction of working motivation through job characteristics: The role of internal motivation, general and growth satisfaction. International Journal of Education and Applied Sciences, 1(1), 48 - 54.

Noraini Idris. (2010). Penyelidikan dalam pendidikan. Kuala Lumpur, Malaysia: McGraw Hill (Malaysia) Sdn. Bhd.

Norashid Othman, \& Hamzah Md. Omar. (2014). Beban tugas dan motivasi pengajaran guru di sekolah menengah Daerah Ranau, Journal Pemikir Pendidikan, 5, 35 - 57.

Preacher, K. J., \& Hayes, A. F. (2008). Asymptotic and resampling strategies for assessing and comparing indirect effects in multiple mediator models. Behavior Research Methods, 40(3), 879 - 891. doi: 10.3758/BRM.40.3.879.

Rabia Hadi, \& Adnan Adil. (2010). Job characteristics as predictors of work motivation and job satisfaction of bank employees. Journal of the Indian Academy of Applied Psychology, 36 (2), $249-299$. 
Renn, R.W., \& Vandenberg, R.J. (1995). The critical psychological states: An underrepresented component in job characteristics research. Journal of Management, 21(2), 279 - 303.

Richey, R.C., \& Klein, J.D. (2007). Design and development research. Mahwah, NJ: Lawrence Erlbaum Associates Publisher.

Saifulizam Mohamad. (2011, 7 Oktober). 1.2j penjawat awam naik gaji. Utusan Malaysia, p. 1. Diperoleh daripada http:// www.utusan.com.my/utusan/info.asp?y=2011\&dt= 1008 \&sec=Muka_Hadapan\&pg=mh_02.htm

Shani, N., \& AnandKumar, V. (2011). A study on job characteristics and internal work motivation among ICICI bank employees. International Journal of Management, 2(2), 56 - 65.

Shrout, P.E., \& Bolger, N. (2002). Mediation in experimental and nonexperimental studies: New procedures and recommendations. Psychological Methods, 7 (4), 422 - 445.

Subasi, G. (2009). I want to become an English teacher in Turkey because...International Journal of Arts and Sciences, 3(5), $137-175$.

Toode, K., Routasalo, P., Helminen, M., \& Suominen, T. (2014). Hospital nurses' individual priorities, internal psychological states and work motivation. International Nursing Review, $61,361-370$.

Treadgold, R. (1999). Transcendent vocations: their relationship to stress, depression and clarity of self concept. Journal of Humanistic Psychology, 39 (1), 81 - 105.

Yalom, I. D. (1980). Existential psychotherapy. New York, USA: Basic Books 